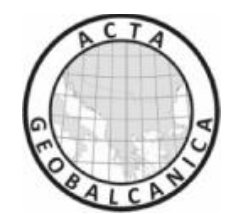

\title{
THERMAL MATURITY ASSESSMENT OF MIDDLE TRIASSIC ROCKS AND HEAT FLOW MODELING IN AGATOVO-SUHINDOL AREA (CENTRAL NORTH BULGARIA)
}

\author{
Assoc. Prof. Dr. Nikola Botoucharov ${ }^{1}$ \\ Megi Angelova, BSc. ${ }^{1}$ \\ ${ }^{1}$ Sofia University “St. Kliment Ohridski”, Bulgaria. \\ Corresponding author: botnd@gea.uni-sofia.bg
}

\begin{abstract}
The study area is in the Moesian Platform and more precisely in its southern most subsided part - South Moesian Platform Margin. The research object is Triassic section reached by boreholes in the Agatovo and Suhindol countryside area. The data base is mainly from 4 key wells - from west to east R-1 Agatovo, $R$-2 Suhindol, R-2 Agatovo and R-1 Suhindol. Geological and drilling information enables modeling of thermal evolution and heat flow in a broader age range. Therefore, allowing reconstruction of the geodynamic evolution in the study area. It is an important factor for the subsidence and transformation of organic matter in sedimentary rocks as well as generation of oil and gas.

The main objective of the research is to assess the thermal maturity of Middle Triassic rocks and modeling heat flow by the measured vitrinite reflectance (\% Ro) in Mesozoic section. Thermal maturity of the Middle Triassic sediments varies between 1.09 and $1.79 \%$ Ro, which define them as mature to overmature deposits within the stages of hydrocarbon generation. This is a result of the great thickness of overburden rocks and burial depths of the Triassic sediments. Typical of the region is that the thermal maturity of the Triassic sediments increases from north to south, as in the same direction increases the thickness and depths not only of Lower-Middle Jurassic sequence, but of the entire Mesozoic complex.

The compiled 1-D geothermal model shows that during the deposition of the Middle Triassic sediments there were increased values of the heat flow. They are inherited from earlier extensional tectonics caused by the Late Permian and Early Triassic rifting. The study area model calculations demonstrate a heat flow of over $60 \mathrm{~mW} / \mathrm{m}^{2}$ for the Anisian-Carnian age interval. Since the end of Carnian and in NorianRhaethian time the heat flow has been lower than in previous Triassic epochs and up to $50 \mathrm{~mW} / \mathrm{m}^{2}$. This is a consequence of compressional tectonics during Cimmerian orogenesis in the Late Triassic leading to uplift and erosion of part of the section. Following the logic of the pattern we can summarize that the heat flow rises in stages of extension in the Triassic and Jurassic reaching values of up to $80-85 \mathrm{~mW} / \mathrm{m}^{2}$ in Early-Middle Jurassic. And vice versa in periods of denudation heat flow decreases. Modeled heat flow decreases gradually thereafter, to remain around $50 \mathrm{~mW} / \mathrm{m}^{2}$ from Late Jurassic until the Quaternary.
\end{abstract}

Keywords: Moesian Platform, Middle Triassic, thermal maturity, heat flow, modeling 


\section{INTRODUCTION}

The study area is in the Moesian Platform and more precisely in its southern most subsided part - South Moesian Platform Margin (Fig. 1). The Platform has been arena for intense geological surveys for oil and gas and accumulated a large amount of drilling and geophysical information till now. The interest in this area is for many years because of industrial oil and gas-condensate fields as well as numerous oil and gas shows which are mainly in the Triassic sedimentary complex.

The research object of the paper is the Triassic section reached by boreholes in the Agatovo and Suhindol countryside area. The data base is mainly from 4 key wells from west to east R-1 Agatovo, R-2 Suhindol, R-2 Agatovo and R-1 Suhindol. Geological and drilling information enables modeling of thermal evolution and heat flow in a broader age range. Therefore, allowing reconstruction of the geodynamic evolution in the study area. It is an important factor for the subsidence and transformation of organic matter in sedimentary rocks as well as generation of oil and gas.

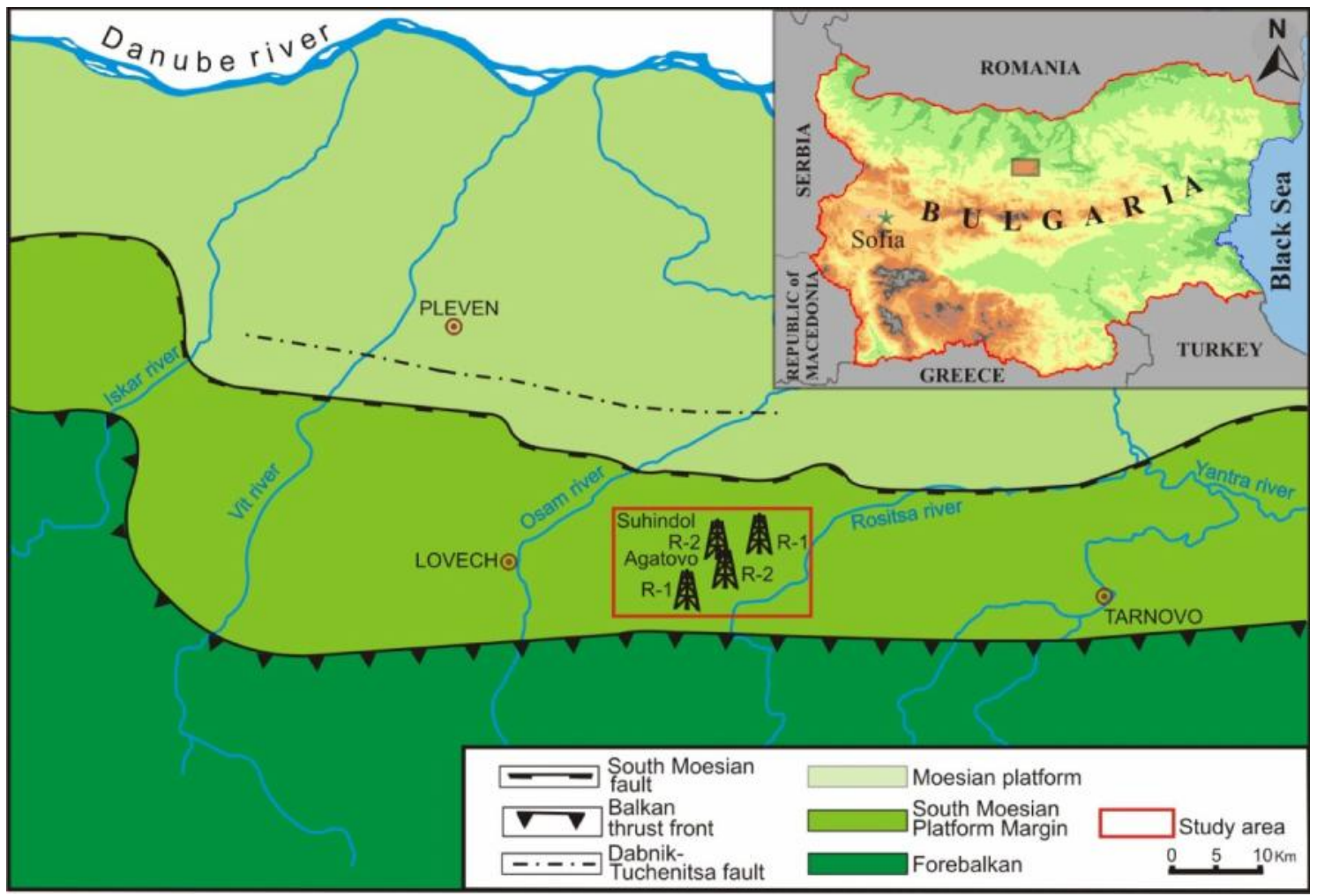

Figure 1. Tectonic scheme of Central North Bulgaria and study area.

The main objective of the research is to assess the thermal maturity of Middle Triassic rocks and modeling heat flow by the measured vitrinite reflectance (\% Ro) in Mesozoic section.

\section{GEOLOGY AND TECTONICS}

The Moesian Platform evolved in the geological setting of the East European continental margin and forms part of northern Peri-Tethyan shelf system [1, 2, 3, and 4]. The Moesian Platform as the southern promontory of the East European Platform is 
separated on its NE side from Scythian Platform by the North Dobrudja orogen. To the north, west and south the Moesian Platform is limited by the arcuate Alpine thrust fold belt, comprises the Southern Carpathians and Balkanides, extending eastward to the Black Sea. The Northern Bulgaria is occupied by southern part of Moesian Platform. The sedimentary platform succession, locally thick up to $12-13 \mathrm{~km}$, is composed by Paleozoic, Mesozoic and Neozoic sequences, covering a pre-Paleozoic metamorphic basement.

The southern part of the Moesian Platform in Bulgaria is presented by the South Moesian Platform Margin. The South Moesian Platform Margin was repeatedly affected by generally N-S directed compressions and extensions. The Mid Cretaceous and MidEocene compressional events resulted in strong platform margin shortening and forming of thrust-folded Balkan orogen belt [3, 4].

The present-day structure of the Platform Margin is a west-east trending 20-40 km wide subsided zone, lying between the Balkan thrust front and the southern edge of the Moesian platform, marked by the South Moesian fault (Fig 1). The margin is characterized by a complex south-deepening monoclinal structure.

\section{TRIASSIC LITHOSTRATIGRAPHY}

The Triassic sediments in the Moesian platform occur in great depths and their investigation started with the oil and gas drilling and exploration. The Triassic sequence comprises continental and dominantly shallow marine sediments with maximum thickness rarely more than 1000-1500 m in Central North Bulgaria. They are intensively faulted on numerous vertically displaced blocks, in which the pre-Jurassic erosion reached different level up to Lower Triassic basal beds and top of Paleozoic basement (Fig. 2).

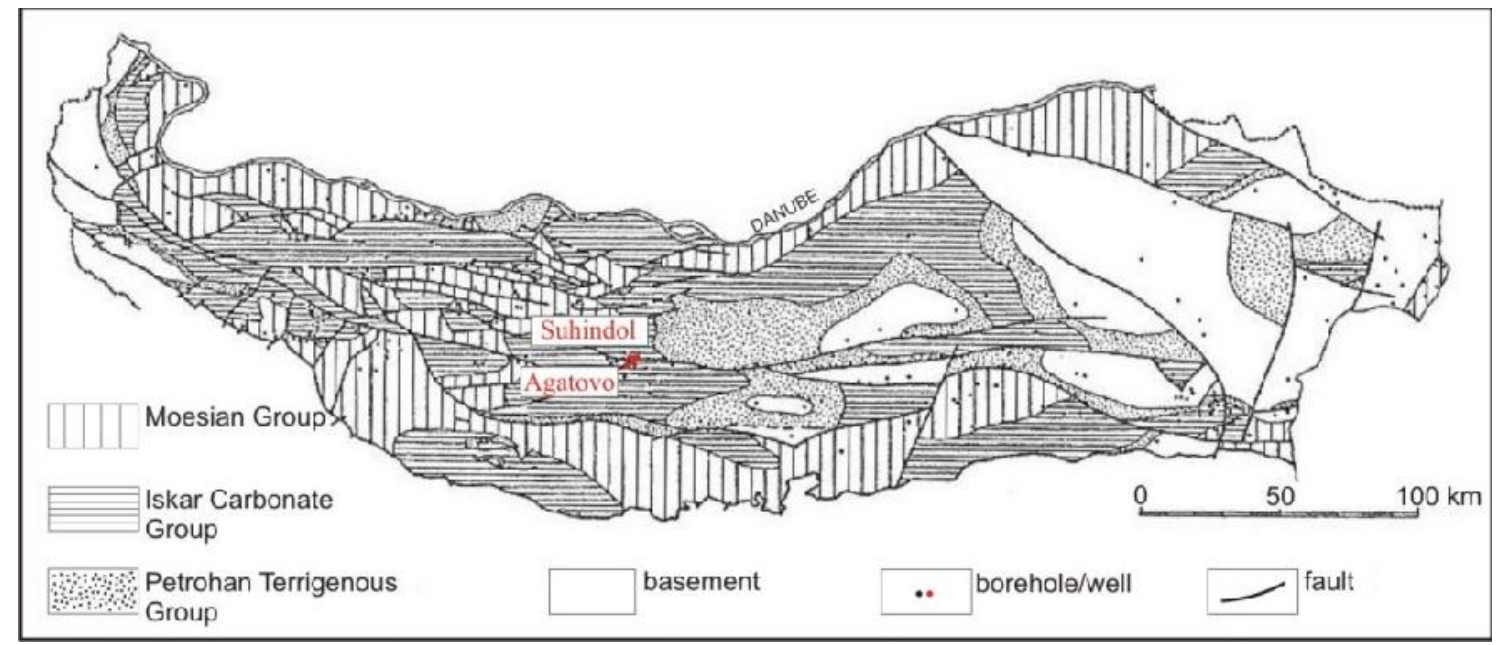

Figure 2. Triassic Group distribution in North Bulgaria with investigated wells (after [4]).

Balkanides or Peri-Tethyan Triassic type is the most widespread type of autochthonous Triassic presented in the Moesian platform [5]. There are three groups in Bulgarian part of the Moesian Platform in ascending order: Petrohan Group, Iskar Group and Moesian Group (Fig. 3). Spatial relationships between different Triassic Groups and Formations in North Bulgaria are complex and determined by the number of facial substitutions, wedge like contacts and sedimentation variations during their deposition. 
Petrohan Group in study area consists of terrigenous-argillaceous and mostly red and variegated rocks. The sediments were deposited in an alluvial plain (Red bed sandstone unit) and in a transitional environment marking transgression in paralic depositional systems (Stejerovo Formation and Alexandrovo Formation). The chronostratigraphic position is a lower Triassic series - the lowermost parts of the Anisian stage.

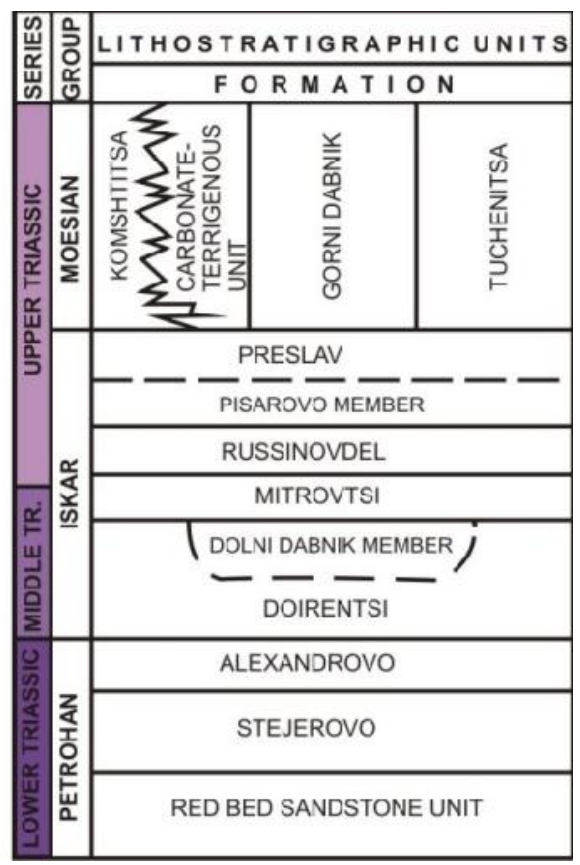

Figure 3. Lithostratigraphic scheme of the Triassic sediments from well cross-sections in Central North Bulgaria (after [6]).

Iskar Group is mainly of grey carbonates and carbonate-terrigenous-argillaceous rocks (Fig. 3). The age is Middle-Late Triassic. The Group includes several Formations all of them deposited in a shallow, epicontinental sea basin during Anisian, Ladinian and Carnian.

Moesian Group is composed of a diversity of carbonate-terrigenous rocks (Fig. 3). The chronostratigraphic position is Upper Triassic series. The Formations deposited in quite varied, transitional and continental environments. The Formations join together mainly in lateral direction and often their relationships are complex.

\section{DATA AND METHODS}

The rocks of the Moesian Group and part of the Iskar Group are totally eroded and Middle Triassic sediments with Anisian age are denudated to different depth levels in the study area. The investigated well cross-sections also do not reach the Lower Triassic rocks. Therefore, the sampling for vitrinite reflectance measurements in Triassic series is limited mainly to Doirentsi Formation (Table 1).

The maturity of 5 Triassic samples selected from 4 wells was determined (Fig. 1, 2 and Table 1). Vitrinite reflectance of another 17 additional Jurassic and Cretaceous samples was measured in order to define the thermal history of the drilled Mesozoic succession in the study area. All of the drilled sections of wells R-1 and R-2 Agatovo, and R-1 and 
R-2 Suhindol were modeled, showing common geodynamic and heat flow history. The well R-1 Agatovo was selected as representative by available data and results.

Table 1. Database of the samples for vitrinite reflectance (\%Ro) in investigated wells.

\begin{tabular}{lcccc}
\hline \multicolumn{1}{c}{ Well } & Formation & Sample № & Depth $(\mathbf{m})$ & Ro(\%) \\
\hline R-1 Agatovo & Urgon complex & 1 & 329.0 & 0.51 \\
\hline R-1 Agatovo & Gorno Oryahovo & 2 & 1652.0 & 0.70 \\
\hline R-1 Agatovo & J3+K1vlg & 3 & 3197.6 & 0.98 \\
\hline R-1 Agatovo & Bov & 4 & 3599.5 & 1.36 \\
\hline R-1 Agatovo & Ozirovo & 5 & 4527.4 & 1.67 \\
\hline R-1 Agatovo & Doirentsi & 6 & 4771.0 & 1.79 \\
\hline R-2 Agatovo & Gorno Oryahovo & 7 & 688.5 & 0.39 \\
\hline R-2 Agatovo & Gorno Oryahovo & 8 & 1201.0 & 0.54 \\
\hline R-2 Agatovo & Gorno Oryahovo & 9 & 2085.0 & 0.80 \\
\hline R-2 Agatovo & Bov & 10 & 3286.0 & 1.03 \\
\hline R-2 Agatovo & Etropole & 11 & 3648.5 & 1.27 \\
\hline R-2 Agatovo & Ozirovo & 12 & 3854.4 & 1.39 \\
\hline R-2 Agatovo & Doirentsi & 13 & 4153.5 & 1.68 \\
\hline R-1 Suhindol & J3+K1vlg & 14 & 3035.0 & 0.74 \\
\hline R-1 Suhindol & Etropole & 15 & 3412.6 & 0.81 \\
\hline R-1 Suhindol & Doirentsi & 16 & 3833.0 & 1.09 \\
\hline R-1 Suhindol & Doirentsi & 17 & 4031.0 & 1.16 \\
\hline R-2 Suhindol & Gorno Oryahovo & 18 & 1291.5 & 0.48 \\
\hline R-2 Suhindol & Gorno Oryahovo & 19 & 2188.0 & 0.60 \\
\hline R-2 Suhindol & Ozirovo & 20 & 3594.4 & 0.80 \\
\hline R-2 Suhindol & Ozirovo & 21 & 3796.0 & 1.05 \\
\hline R-2 Suhindol & Doirentsi & 22 & 3951.0 & 1.11 \\
\hline
\end{tabular}

PDI-1D software of IES, Jülich, was used to reconstruct the heat flow. The calculation of vitrinite reflectance followed the kinetic "Easy \%R" algorithm [7].

\section{MATURITY ASSESSMENT AND HEAT FLOW MODELING}

The main task of the research is to assess the thermal maturity of Middle Triassic rocks as part of overall thermal evolution in study area. Furthermore, it is a prerequisite for modeling heat flow by the measured vitrinite reflectance (\% Ro) in Mesozoic section (Table 1).

Thermal maturity of the Middle Triassic sediments is the highest and varies between 1.09 and $1.79 \%$ Ro, which define them as mature to overmature deposits. This is a result of the great thickness of overburden rocks and burial depths of the Triassic sediments. However, the source rocks with higher organic matter content in Central North Bulgaria are Lower-Middle Jurassic shales and clayey carbonates. Therefore, the thermal history after their deposition is even more important for oil and gas generation. Analysing vitrinite reflectance data from Table 1 we see the same two maturity stages (mature and over mature) for sediments of Ozirovo, Etropole and Bov Formations $\left(\mathrm{J}_{1-2}\right)$. 
Comparing the maturity of the three Formations the samples of Ozirovo demonstrate the highest values of 1.6-1.7\%Ro, because these rocks are buried at depths more than 3500 $\mathrm{m}$ and in well R-1 Agatovo even more than $4500 \mathrm{~m}$. These results allow us to make further reconstruction of the geodynamic development and modeling of Mesozoic heat flow in the study area. We choose to present the thermal evolution with model of temperature and vitrinite reflectance variations in well R-1 Agatovo, adding some additional measurements from neighboring wells (Fig. 4). Maturity trends in study area, as part of South Moesian Platform Margin, during Mesozoic are the outcome of geodynamic evolution, expressed generally in stages of intense subsidence after extensional phases and the following and interrupting compressional, north-verging movements.

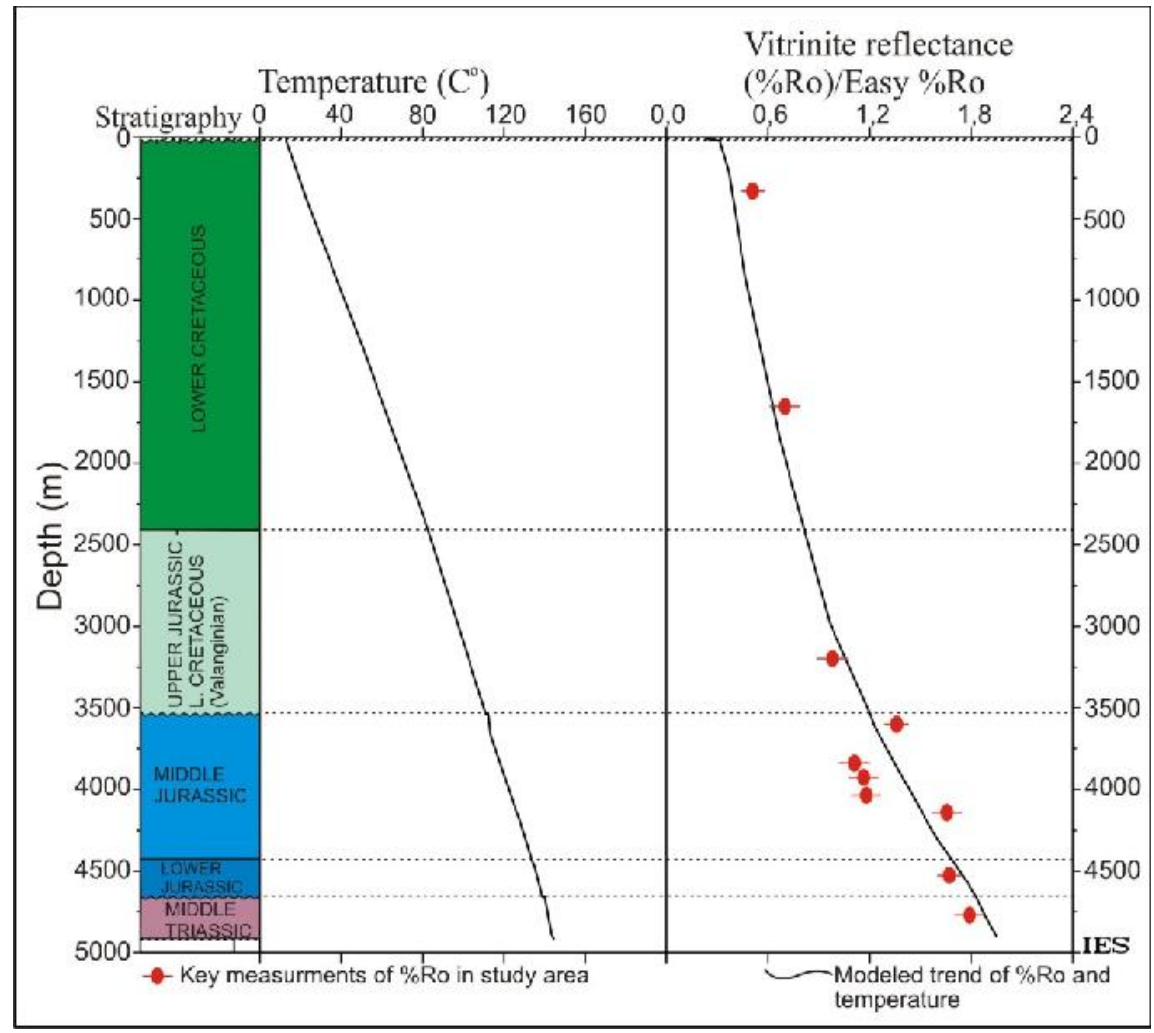

Figure 4. Generalized model of measured vitrinite reflectance (\%Ro) in well R-1 Agatovo with additional maturity data from neighboring wells.

Typical of the region is that the thermal maturity of the Triassic sediments increases from north to south, because of the highest burial depths. Furthermore, in the same direction increases the thickness and depths of Lower-Middle Jurassic sedimentary section and as a consequence of that of the entire Mesozoic complex.

The heat flow history of the South Moesian Platform Margin is difficult to define in great details due to the complicated geodynamic evolution of this area, which is consistently affected by Mesozoic rifting cycles that were interrupted and followed by compressional events. All this had an impact on the rate and type of sedimentation, and therefore the time and degree of maturity of the buried rocks and related organic matter. The reconstruction and modeling of heat flow were made on the basis of the measured values of the vitrinite reflectance, which is one of the most used and reliable palaeotermometers (Fig. 4 and 5). 
All models and especially that for the well R-1 Agatovo show that during the deposition of sediments in Triassic and Early-Middle Jurassic the palaeo-temperatures were relatively low for generation of hydrocarbons (Fig. 5). The buried depths were not enough for maturation of the organic matter and expulsion of oil and gas. Later the deposition of new sequences some with greater thickness led to accumulation of significant sedimentary "pile". The enlargement of the latter and increase of the burial depth and temperatures stimulated the sharp peak of maturity after Valanginian. The computer generated palaeo-temperature curves and vitrinite reflectance trend show that early hydrocarbon generation was at depths of about 1600 meters, sometime in the Early Cretaceous. There are two earlier peaks related to extensional tectonics and thinning of the lithosphere. In Late Jurassic and Early Cretaceous until Hotrivian the increase of the temperature is relatively gradual with higher trend afterwards. The highest temperatures are in Barremian and Aptian stages when the maximum burial depths are reached.

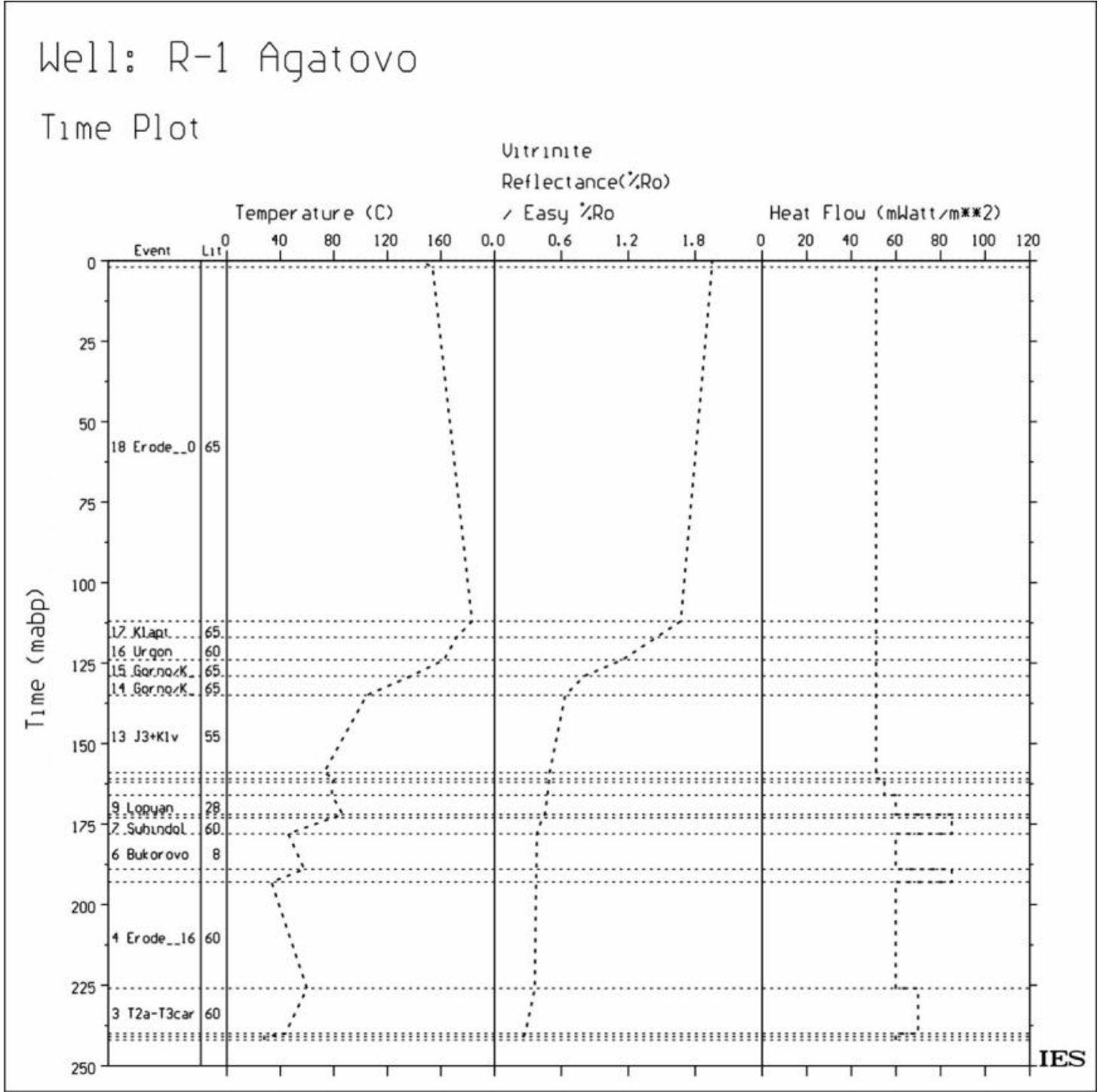

Figure 5. Model of the temperature, vitrinite reflectance and heat flow during geological evolution for the key well in the study area.

The compiled 1-D geothermal model also shows that during the deposition of the Middle Triassic sediments there were increased values of the heat flow. They are 
inherited from earlier extensional tectonics caused by the Late Permian and Early Triassic rifting. The study area model calculations demonstrate a heat flow of over 60 $\mathrm{mW} / \mathrm{m}^{2}$ for the Anisian-Carnian age interval. Since the end of Carnian and in NorianRhaethian time the heat flow has been lower than in previous Triassic epochs and up to $50 \mathrm{~mW} / \mathrm{m}^{2}$. This is a consequence of compressional tectonics during Cimmerian orogenesis in the Late Triassic leading to uplift and erosion of part of the section. Following the pattern we can summarize that the heat flow rises in stages of extension in the Triassic and Jurassic reaching values of up to $80-85 \mathrm{~mW} / \mathrm{m}^{2}$ in Early-Middle Jurassic. And vice versa in periods of denudation heat flow decreases. Modeled heat flow decreases gradually thereafter, to remain around $50 \mathrm{~mW} / \mathrm{m}^{2}$ from Late Jurassic until the Quaternary.

\section{CONCLUSION}

Geological and geophysical data from investigated wells allowed characterizing the lithology, stratigraphy, the spatial position of the Triassic section and creating a geodynamic model for the Mesozoic evolution of the Agatovo-Suhindol area (Central North Bulgaria).

Middle Triassic series has reached a high level of thermal maturity and Upper Triassic rocks are completely eroded and/or primary missing. There is a clear trend of an increase in the \%Ro values from north to south towards the Balkanides.

Measured vitrinite reflectance allowed also modeling of heat flow in the Mesozoic. The observed trends are result of the complex geodynamic evolution including extensional phases with higher heat flow and episodic north directed compression events with lower or decreasing heat flow.

Acknowledgements: The authors thank the National Resources and Concessions in Ministry of Energy, Bulgaria for providing the geological, geophysical and well data.

\section{REFERENCES}

[1] Georgiev, G. \& Dabovski, C. Alpine structure and Petroleum Geology of Bulgaria, Geology and mineral resources, 8-9, pp 3-8, 1997. (in Bulgarian).

[2] Georgiev, G., \& Dabovski, C. Rifting and Thrusting in Southern Moesian Platform Margin - Implications for Petroleum Geology, In: EAGE 62nd Conference and Technical Exhibition, SECC, Glasgow-Scotland, Extended Abstracts, Volume 2, 2000.

[3] Georgiev, G., Dabovski, C. \& Stanisheva-Vassileva, G. East Srednogorie-Balkan Rift Zone, In: Ziegler, P.A., Cavazza, W., Robertson, A.H.F. \& Crasquin-Soleau, S. (Eds), Peri-Tethys Memoir 6: PeriTethyan Rift/ Wrench Basins and Passive Margins. Memories du Museum National d'Histoire Naturelle, 186, pp 259-293. 2001.

[4] Chemberski, H., Rankova, T., Antova, N. \& Nikolov, G. Triassic system in Bulgaria - material composition, sedimentary environment and geodynamic events, Review of the Bulgarian Geological Society, 57, 2, pp 1-18, 1996. (in Bulgarian).

[5] Zagorchev, I \& Budurov, K. Outline of the Triassic paleogeography of Bulgaria, Albertiana, 19, pp 12-24, 1997. 
[6] Chemberski, H. A regional lithostratigraphic scheme of the Triassic sediments from well cross-sections in the North Bulgaria (Development of the Ideas), Oil Coal Geol., vol. 21, pp 53-56, 1985. (in Bulgarian).

[7] Sweeney, J. \& Burnham, A. Evaluation of the simple model of vitrinite Reflectance based on chemical kinetics, AAPG Billetin, 74, pp 1559-1570, 1990. 